Studia Anglica Posnaniensia 52(1), 2017

doi: 10.1515/stap-2017-0002

\title{
MEASURES IN MEDIEVAL ENGLISH RECIPES - CULINARY VS. MEDICAL
}

\author{
MAgDAlena BATOR AND Marta SYLWANOWICZ*
}

University of Social Sciences, Warsaw

\begin{abstract}
$^{1}$
The present paper deals with an analysis of medieval culinary and medical recipes. A major feature which will be of interest is the use of measure terms. The research has been based on material from $14^{\text {th }}$ and $15^{\text {th }}$ century recipe collections. First, the major weight and measure systems which were used in the Middle English period will be presented. Then, the measure terms used in the analysed texts are collected and categorised into three groups: specific, non-specific, and container-related terms. The study, apart from showing the variety of measure terms used at the time, also compares two types of recipes, i.e., medical and culinary.
\end{abstract}

Keywords: recipe; culinary; medical; medieval; measurement

\section{Introduction}

Middle English recipes, both culinary and medical, have received attention of many scholars. In these studies recipes have often been analysed from the point of view of a genre and/or a text type. ${ }^{2}$ Taavitsainen (2004: 75) defines the former "according to language-external evidence" (i.e., function, audience, and occasion); whilst the latter on the basis of linguistic criteria. Thus, a genre is usually identified by the function it fulfils in society (cf. Swales 1990;

\footnotetext{
Corresponding author: Magdalena Bator, School of English, University of Social Sciences, ul. Lucka 11, 00-842 Warsaw, Poland, e-mail: mbator@ spoleczna.pl

1 Project financed by the National Science Centre, decision number DEC2013/11/B/HS2/02504.

2 See for instance Görlach (1992, 2004), Alonso Almeida (1998-1999, 2008, 2009, 2013), Jones (1998), Carroll (1997, 1999, 2004, 2005-2006), Taavitsainen (2001a, 2001b, 2012), Mäkinen (2004, 2006), Marttila (2014), etc.
} 
Taavitsainen 2012). In this functional view, the recipe is a genre whose main function is to give "instructions on how to prepare medicine, a dish, or some household utility like ink"3 (Taavitsainen 2001a: 86). As regards the recipe as a text type, it is usually examined according to its formal, linguistic features ${ }^{4}$. The typical recipe features include "a set form of a title, imperative forms of verbs, short paratactical sentences following temporal sequence of instructions to be carried out, object deletion, measurement specifications, and formulaic endings" (Taavitsainen 2001b: 142). Görlach (2004: 124) adds "full sentences or telegram style", "use of possessive pronouns with ingredients and implements", "complexity of sentences", and "marked use of loanwords and of genteel diction".

The present paper deals with Middle English recipes from the $14^{\text {th }}$ and $15^{\text {th }}$ centuries. Two coexisting types of recipes will be analysed and compared, i.e., culinary and medical recipes. The main aim of this paper is to examine the use and distribution of measurement specifications ${ }^{5}$ in the analysed texts. In doing so, we will attempt to answer the following questions: (i) what measure units (if any) were used in the recipes? (ii) did the recipes (culinary and medical) coincide in the use of measure terms? (iii) was the use of measure terms conditioned by the type of a recipe? Also, we will propose a classification of measurement specifications used in culinary and medical recipes.

3 Carroll (2004: 188), in her study of selected culinary and medical Middle English recipes, found examples of recipes that apart from telling "how to make things" instruct "how to do things". For instance, in the case of medical recipes, we find examples where the text is not about how to make medicine but how to use some ingredients in order to cure a given ailment.

4 For a discussion on the classification of text types, see, e.g., Werlich (1976). He distinguishes five elementary text types (narrative, instructive, expository, argumentative, and descriptive), and describes their characteristic linguistic features. Instructive texts (e.g., recipes) are characterised by "the use of commands or requests, first- or second-person point of view, topical coherence, topic-giving instructions, and a text structured either analytically or like a list" (Werlich 1976: 122-125, after Carroll 2004: 178).

5 There is no comprehensive study that would focus solely on the use of measurement specifications in Middle English recipes and compare their use in medical and culinary recipes. The earlier studies deal with this text type feature briefly, often incorporating it in the discussion of other text type features of a recipe. For instance, Görlach (2004: 130) in his discussion of the culinary recipe as a text type, gives only a short comment on measure terms. Carroll (2009: 61-64) in her study of vague language in culinary recipes offers a classification of measurements (precise and vague quantities). As regards medical recipes, Taavitsainen (2001a: 103) offers a general comment on the use of measures and suggests that there is a difference in the use of these terms depending on the level of text, i.e., more precise measurements are typical for texts representing academic tradition. These studies, however, apart from giving a few quotations that illustrate the use of the terms, do not discuss their frequency or distribution. See also the studies by Pocuca \& Stupar (2006), Alonso Almeida (1998-1999, 2013). 
In what follows, the two types of recipes will be briefly characterised, and the major metrical systems used in the British Isles will be illustrated. Next, the measure terminology found in the analysed corpus will be discussed and a comparison between the culinary and medical material will be offered.

\subsection{The culinary recipe}

Medieval culinary recipes have been categorised as "texts where the instructional function has not been made explicit by the producer. (...) In terms of their language, however, the recipes represent an almost prototypical example of texts employing instructional features" (Tanskanen, Skaffari \& Peikola 2009: 7). Their function was to consult rather than to teach, which, following Carroll (2009: 79), could be accounted for by "the amount of common ground that can be assumed to exist between the original author of the recipe and the reader". The recipes were more like lists of ingredients defining the order of adding them and not detailed instructions guiding the cook step by step how to prepare a particular dish. Food historians, such as Hammond (2005) or Scully (1995), claim that the recipes must have functioned as aids for the chief cook rather than for those working in the kitchen, who must have worked by memory and experience. They might have been written down in order to remind the cook of the ingredients needed to prepare a feast, so that when a menu was chosen, the recipes were used to prepare a certain type of a "shopping list". They might also have been of help for the cook in order not to forget about any ingredient or about the order of adding particular ingredients. Following Brears (2008), the cook's memory had to be refreshed, i.e., they remembered the frequently prepared dishes, such as pastries or bread, and most basic processes, such as plain boiling or roasting ${ }^{6}$, but details concerning food which was not in everyday use might have been forgotten. On the other hand, Scully (1995) points out that recipes were not written for the cook, who was a professional and knew well enough how to prepare particular dishes, but by the cook (as some archival material). He writes:

A recipe collection was compiled in manuscript form not for the cook in a noble or bourgeois household but for the master or mistress of that household. It served to document certain standards of an elite class. Occasionally revised with additions, deletions and modifications, occasionally copied, with the approval of the master or mistress in order to please a flattering friend or relative, a manuscript collection of recipes reposed in the household library, not in its kitchen.

(Scully 1995: 8)

6 For a discussion of the Middle English vocabulary referring to cooking procedures, see Carroll (1997) and Bator (2013a, 2013b, 2014). 
Scully notices that the majority of the surviving recipes are too clean to ever have been used in the kitchen. The content of the recipes suggests that the most outstanding chefs were not willing to reveal details of their craft. For instance, Guillaume Tirel, one of the greatest chefs in $14^{\text {th }}$ century France, the author of the Viandier, ${ }^{7}$ explained the omission of instructions on how to cook some of the dishes included in his collection thus: "everyone knows how to do them. (...) as for tripe, which I have not put in my recipe book, it is common knowledge how it is to be prepared" (The Viandier of Taillevent, cited after Henisch 2009: 19). On the other hand, the cook gives detailed descriptions of very complicated and sophisticated dishes, which only a master cook with a group of qualified assistants could stand a chance of preparing, which may be a way of boasting about his competence.

Comparing to their French counterparts, the English recipes were much less detailed. However, the character of recipes changed with time. The later a recipe, the more details it contains, although a few cases in which the $15^{\text {th }}$ century recipe is shorter than its $14^{\text {th }}$ century equivalent were also found (see example (1a-b) below). Together with the length of the description, the nature of the recipes evolved too. Studies show that the same recipe changes over time in terms of the ingredients used for its preparation, way of cooking, or seasoning (e.g., Hammond 2005). Hence, following recipes with the same title but coming from different periods, one may come up with a different dish (see, for instance, Myers 2006). Hieatt \& Butler (1985: 9) explain the change of recipes over time in such a way: "these recipes were passed down through succeeding generations, however, there was a tendency to spell out procedures at greater and greater length and to add and/or vary ingredients". The change in the structure of the recipe might have also resulted in the change of the audience at which it was directed (see, e.g., Carroll 2009, Diemer 2013, Bator 2016).

(1a) $14^{\text {th }}$ century:

A tenche in syuee. Scalde py tenche $\&$ atyre wel $\&$ boyle it; $\&$ tak pe same broth $\&$ myed bred \& tempere it togedere, \& tak good poudre / of canel \& of clowes \& do to pe sewe, \& coloure it with safroun $\&$ salte it $\&$ lete hit boile. $\&$ tak myced onyounnes $\&$ frye hem in oyle dolyf or vynegre or in wyn or in pe same broth, \& do hem in pat sewe $\&$ sesen it vp with vynegre or with eysel; \& after pat lat it no more boyle.

(Utilis Coquinario_ A tenche in syuee)

7 Guillaume Tirel (also known as Taillevant) is believed to have lived from around 1312 to 1395. He served in a number of noble households. In 1373 he became the head cook of Charles V and then of Charles VI. The Viandier is one of the best known French culinary collections. It was most probably compiled in the 1370s. It is a compilation of dishes gathered by Tirel from earlier sources (Mennell 1996: 50). An edition of the Viandier with translation into English has been published by Scully (1997). 
(1b) $15^{\text {th }}$ century:

Tenche in cyueye. Take a tenche, an skalde hym, roste hym, grynde Pepir an Safroun, Brede an Ale, \& melle it to-gederys; take Oynonys, hake hem, an frye hem in Oyle, \& do hem per-to, and messe hem forth.

(Potage Diverse_ Tenche in cyueye)

The structure of most of the medieval culinary recipes consists of the heading, which consists of the title and/or the statement of purpose, and the preparation. ${ }^{8}$ The title usually depicts the cookbook's repository. It may include the name of the dish or the main ingredient used for its preparation (Carroll 1999). The headings might also refer to a particular quality in the dish, such as the colour of the dish, the method of cooking or the type of the dish. "Recipe names sometimes reveal traditional influences and evolving patterns" (Laurioux 1999: 297). The English dish names very often reflect the French origin of the recipe. Even though the dish might have evolved into a different one than its French counterpart, not only in terms of the amount of details given in the recipe but also in the entire character of the dish; the recipe might even present a completely different dish than the one described in the French recipe of the same title (Hieatt \& Butler 1985). Moreover, a number of recipes with a French looking title were never found in any of the French collections, e.g., Viaunde de Cypre (Diversa Cibaria), which suggests that the Anglo-Norman cooks developed their own recipes (see Hieatt \& Butler 1985: 6).

Among the major distinctive features of the recipe Görlach (1992) enumerates sentence structure, verbal forms, temporal sequence, the use of pronouns, and the form of the heading. Carroll (1999) adds a certain degree of technical language and the lack of quantifications. It is the latter feature which is of greatest importance for the present study and which will be discussed in detail.

\subsection{The medical recipe}

English medieval medical recipes are mostly translations or adaptations from Latin and Anglo-Norman originals and they follow the traditions of scientific writing established by Latin medical writers. Thus, in the earliest English medical texts we can find English recipes in company with Latin and/or AngloNorman samples. The predominantly English compilations became widespread in the second half of the $15^{\text {th }}$ century. ${ }^{9}$

8 On the discussion of the structure of English medieval recipes, see Bator \& Sylwanowicz (2017).

9 The process of the vernacularisation of medical writing was facilitated by a number of socio-historical factors. For instance, the increasing number of grammar schools led to the 
Medical recipes are mostly found in remedy books, i.e., texts representing the oldest tradition of medical writing. As Taavitsainen (2001a: 85-86) observes, these recipes "are a well-defined procedural genre with a clear writing purpose" and their text-type features show "a high degree of standardization". Their content is fairly uniform: they usually consist of a title (2a) or statement of their purpose (2b), followed by a list of ingredients, preparation and dosage, administration, justification of use, and additional information ${ }^{10}$ (Taavitsainen 2001a: 86, Mäkinen 2004: 146).

(2a)

[\}ADRIANUM.\}] Yt ys cleped of Adryan, Emperor of Rome, be wyche yt compownde. Yt ys goode properlyche to alle [lf. 3rl] euel of pe hed of coldnes, and to greuance of be eyzen, and to derkenes of hem, and to the mygrayne. Take opium theobaicum, III dragmes; cassia lignea, henebane sed, of eyper [\{II $\{$ ] dragmes II scripules and half; ewforbe, whyte peper, of eche II dragmes and VI corne wyght and pe pridde parte of a corne of whete; $(.$.

Be yt [lf. 3vl] zeue wyp hote weyne in pe wyche sauge hathe be ysode ynne in pe maner of an auellane. Be yt zefe to hem pat hauepe pe feuere quarteyne wyp decoction of gencyan or wylde rewe, byfore the howre of acces. Be yt zef alsoo to pe pacyent pat bygynnep to haue the ston wyp wyn in pe wyche gromyle or saxifrage hape be sode ynne.

(MEMT, Antidotarium Nicholai)

An electuarie pat restorip a man-is mynde and comfortep his brayn and / al his body: Take of canel, roses, violet, ginger, cardamomum, of eueriche, oz. ii; of dragagantum, antos, bawme pat ia an herbe, maioran, pe rynde of myrtille, ciperi, liquoris, siler, of eueriche, oz. ii; of squinantum, spike, clowes, quibibis, folii, galange, auence, borage, sene, bean, spodie, coral, mastike, macropipir, storax, brent silke, of eueriche, oz. $1 / 2 \&$ sc. i; of sirep of roses, quantum sufficit.

(Getz, Gilbertus Anglicus)

spread of literacy among the middle classes. The rise in the number of readers, in turn, triggered a demand for more writings in the vernacular (Pahta \& Taavitsainen 2004: 15-16). Also, the introduction of the printing press in 1476 triggered the spread of books in the vernacular. Hence, medical practice was often undertaken by people with less or no formal medical training who could read and had access to the medical writings in English (see also Pahta \& Taavitsainen 2004, Pahta 2004, Peter Jones 1999, Claire Jones 2004).

10 Alonso Almeida (2013) adds storage as an additional subsection of the recipe. This part of the recipe gives instructions on how to keep the final product for future use, e.g., kepe yt in a boxe; kepe hit well in a glasse and stoppe hit well (MEMT, Remedies and materia medica). These instructions, however, are rare and seem optional (cf. also Caroll 20052006: 307). In this study, storage instructions, together with, e.g., efficacy phrases, are treated as a part of the justification of use and additional information. 
Recipes are not confined only to remedy books and are also found in texts representing a more learned tradition of writing (surgical texts and specialised treatises). In these texts, however, recipes are rare and they form an integral part of longer treatises, which makes it difficult to discern them from the main body of the text. As Taavitsainen (2001a: 95-96) observes, the beginning and the end of the recipe is often not indicated and the instructional part (usually marked by an imperative form of take) is preceded by the administration part.

The difference in content and the internal structure of recipes allows one to distinguish at least three types of medical recipes, i.e., antidotaria, receptaria, and experimenta (cf. Mäkinen 2004; Hunt 1990).

Antidotaria recipes are often called full recipes (see (2a) above) as they contain all the elements characteristic of the structure of a recipe text, i.e., name/title, list of ingredients and their measures, as well as their preparation and application (Hunt 1990: 8). The remedies included in antidotaria are of a learned character, i.e., mostly derived from Latin originals, and there is no folk medicine ${ }^{11}$ included. Another characteristic feature of antidotaria, in comparison with receptaria or experimenta, is that they usually provide precise and detailed information on weights and measures (Hunt 1990: 8).

The receptaria, unlike antidotaria, are much shorter texts and are usually part of longer medical treatises and arranged according to their purpose (see (2b) above). Thus, most receptaria are recognized by the following introductory lines: A (good, special) medicine for..., Another (medicine) for ..., followed by the name of the sickness or statement of purpose (Getz 1991, Mäkinen 2004). These short recipes often incorporate folk medicine and are characterized by the use of less precise measure terms, e.g., a little, a quantity of, though specified terms are also found, but less frequently.

The last category of recipes, experimenta, are not found in medical or pharmaceutical compilations as they are short passages that were passed down by word of mouth, "jotted down after hearing them from a colleague or an acquaintance who had proved the efficacy of the recipe in practice" (Mäkinen 2004: 147).

\section{Systems of weights and measures ${ }^{12}$}

The paper attempts to provide a general examination of one of the distinctive features of the recipe, i.e., the way of giving measures (mostly weights and amounts). It should be stated that the study of English units of weights or measurements in historical texts seems to be a complex task. The medieval

\footnotetext{
11 Folk medicine or practice, i.e., "the use of remedies derived from experience alone" (Getz 1998: 35)

12 There are separate systems referring to dry and liquid measures. The present paper deals exclusively with the former.
} 
metrologies differed significantly from the contemporary ones. The early (premetric) weights and measures were often assigned locally and adjusted to the local community's needs (Zupko 1990). Originally, the system of measurement used in England was based on the one used in the Roman Empire (Ross 1983). With time, the definitions and understanding of weights and measures changed and particular historical periods witnessed the use of a number of different measure systems. For instance, in the early Middle Ages Celtic as well as Germanic metrological systems replaced the Roman one. In later times, due to such factors as economic and technological development, commercial competition, etc., "[t]ens of thousands of new units were introduced and hundreds of thousands of local variations emerged from the Atlantic seaboard to central and eastern Europe" (Zupko 1990: 4). This includes the British Isles; for instance, the Scottish measures were usually much bigger than their English counterparts (Zupko: 1990: 5-7):

Scots pint (liquid/dry products $)=103.404$ cubic inches $(=\sim 1.701)=2$ choppins $=4$ mutchkins

English pint (dry products $)=33.6$ cubic inches $(=0.5511)$

English pint $($ liquid $)=4$ gills $=28.875$ cubic inches $(=0.4731)$ for wine

$=35.25$ cubic inches $(=0.5781)$ for ale/beer

Scots gallon $($ wine $)=827.232$ cubic inches $(=\sim 13.601)=3.5811$ English gallons $($ wine $)$

Scots tun $($ wine $)=60$ gallons $(=\sim 8.16 \mathrm{hl})$

English tun $($ wine $)=252$ gallons $(=\sim 9.54 \mathrm{hl})$

On the other hand, the Irish equivalents were slightly smaller and the Welsh ones were more or less similar to the English ones. There was also a great deal of variation on a more local level. For instance, the use of area and distance units was often dependent on whether they were applied in cities or in the countryside, on land or at sea; weights and measure units, on the other hand, depended on the product they referred to. The government tried to standardize the system. However, the fact that sometimes a local unit was widespread, and in turn accepted by other regions, contributed to even more discrepancies, i.e., the disparity between state and local units led to even bigger confusion.

Additionally, the set of existing medieval weights and measures was extended by creating subdivisions of the existing units (halves, thirds, fourths, etc.). They were formed by the addition of affixes such as farthing(farthingdale), fer-(ferling), for-(forpit), fur-(furendal), quart- (quartern), etc. And finally, the same term was applied to various categories. For instance, "[t]he pound was also used as a unit of money and as capacity" (Andrew 2008). Such a chaotic situation lasted until the $17^{\text {th }}$ century, when the first successful attempts to standardize the existing system(s) started (Zupko 1990).

According to Ross (1983: 16), we can identify 29 English dry weight systems, seven of which can be regarded as primary systems: (i) the Tower 
Weight; (ii) the Merchants' Weight; (iii) the Hanseatic Merchants' Weight; (iv) the Avoir-du-pois Weight; (v) the Haverdepoise Weight; (vi) the Troy Weight; and (vii) the Avoirdupois Weight. Fig. 1 illustrates the periods when each of these systems was in use.

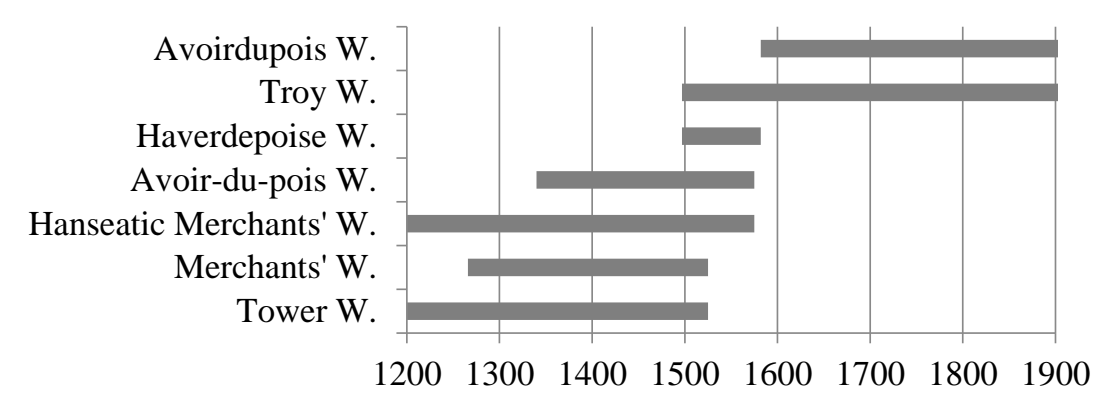

Fig. 1. The major English dry weight systems and the period of their usage (based on Ross 1983: 18) [W. = weight $]^{13}$

The basic units of measurement common to the systems discussed by Ross (1983) were the wheat $(0.04556 \mathrm{~g})$ and the troy grains $(0.0648 \mathrm{~g})$, whereas the largest unit, being identified by the total number of wheat or troy grains, was the pound. The weight standards for the pound varied depending on the metric system: the haverdepoise pound was the heaviest, whereas the tower pound was the lightest of all (see Table 1).

Table 1. The weight standards for the pound in various systems (based on Ross 1983: 19).

\begin{tabular}{l|c|r}
\hline English dry weight pounds & Troy grains & Grams \\
\hline tower pound & 5,400 & 349.92 \\
troy pound & 5,760 & 373.248 \\
merchants' pound & 6,750 & 437.40 \\
avoir-du-pois pound & 6,992 & 453.0816 \\
avoirdupois pound & 7,000 & 453.60 \\
hanseatic merchants' pound & 7,200 & 466.56 \\
haverdepoise pound & 7,680 & 497.664 \\
\hline
\end{tabular}

13 The avoirdupois weight system is, to a certain degree, a continuation of the former avoir-dupois system. In 1582 Elizabeth I established the avoirdupois system to replace the existing weight systems (i.e., the haverdepoise, avoir-du-pois, and hanseatic merchants' weight systems). Its values differ from the ones in the earlier avoir-du-pois system. 
The tower weight system, based on the Arabic silver half dirhem (from Greek drachma) of 22-23 grains, was introduced in 791 by King Offa and was officially abolished by Henry VIII in 1527. In the same year, Henry VIII eliminated the merchants' system that was introduced to England in 1226 by merchants from southern German towns. The hanseatic merchants' system was also brought by German merchants, mostly those from northern Germany. However, this system, together with the haverdepoise and the avoir-du-pois systems, was abolished by Elisabeth I in 1582 (Ross 1983: 20-23).

The two remaining weight systems, the avoirdupois and the troy, were in use until the $20^{\text {th }}$ century and these two systems deserve closer inspection. Additionally, the apothecaries' weight system played an important role in the Middle English period, thus, it shall be discussed in what follows as well.

\subsection{The avoirdupois weight system}

The avoirdupois system (from Anglo-Norman aveir de peis 'goods of weight') was adopted by London merchants in around 1300 and was used for weighing wool or any goods sold in bulk (Ross 1983, Cardarelli 2003). Its basic unit was the pound ( $=7,000$ grains). The other units used in medieval times were the ounce, the stone, and the woolsack. Later, i.e., in post-Elizabethan England, the system was extended by the dra(ch)m, the quarter, the hundredweight, the tone or long tone. The avoirdupois system was commonly used and some countries still resist to replace it with the metric system. Thus, today, it is the everyday system of weight in the United States and, to some degree, in the United Kingdom and Canada. The values for the particular units of the avoirdupois system are shown in Table 2 below.

Table 2. The value of particular units in particular weight systems.

\begin{tabular}{|c|c|c|c|c|c|c|c|c|c|}
\hline \multicolumn{2}{|c|}{$\begin{array}{l}\text { unit } \\
\text { system }\end{array}$} & \multirow{2}{*}{$\begin{array}{c}\text { stone } \\
-\end{array}$} & \multirow{2}{*}{$\begin{array}{c}\text { clove } \\
- \\
\end{array}$} & \multirow{2}{*}{$\begin{array}{c}\text { pound } \\
\mathrm{lb} \text { ap. }\end{array}$} & \multirow{2}{*}{$\begin{array}{c}\text { ounce } \\
\text { oz ap. }\end{array}$} & \multirow{2}{*}{$\begin{array}{r}\text { dra(ch)m } \\
\text { dr ap. }\end{array}$} & \multirow{2}{*}{$\begin{array}{r}\text { penny- } \\
\text { weight } \\
- \\
\end{array}$} & \multirow{2}{*}{$\begin{array}{l}\text { scruple } \\
\text { scr ap. }\end{array}$} & \multirow{2}{*}{$\begin{array}{l}\text { grain } \\
\text { gr ap }\end{array}$} \\
\hline \multirow{5}{*}{ 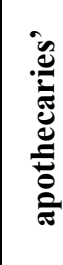 } & symbol & & & & & & & & \\
\hline & & & & 1 & $=12$ & $=96$ & & $=288$ & $=5,760$ \\
\hline & & & & & 1 & $=8$ & & $=24$ & $=480$ \\
\hline & & & & & & 1 & & $=3$ & $=60$ \\
\hline & & & & & & & & 1 & $=20$ \\
\hline
\end{tabular}




\begin{tabular}{|c|c|c|c|c|c|c|c|c|c|}
\hline \multirow{4}{*}{$\stackrel{\overrightarrow{0}}{0}$} & symbol & - & - & $\mathrm{lb}$ troy & oz troy & - & $\mathrm{dwt}$ & - & gr troy \\
\hline & & & & 1 & $=12$ & & $=240$ & & $=5,760$ \\
\hline & & & & & 1 & & $=20$ & & $=480$ \\
\hline & & & & & & & 1 & & $=24$ \\
\hline \multirow{6}{*}{$\frac{.0}{0}$} & symbol & st av. & cv av. & $\mathrm{lb}$ av. & oz av. & $\mathrm{dm}$ av. & - & - & gr av. \\
\hline & & 1 & $=7 / 4$ & $=14$ & $=224$ & $=3,584$ & & & $=98,000$ \\
\hline & & & 1 & $=8$ & $=128$ & $=2,048$ & & & $=56,000$ \\
\hline & & & & 1 & $=16$ & $=256$ & & & $=7,000$ \\
\hline & & & & & 1 & $=16$ & & & $=1750 / 4$ \\
\hline & & & & & & 1 & & & $=875 / 32$ \\
\hline
\end{tabular}

2.2. The troy and the apothecaries' weight systems

The troy system, which was first used in England in the 1400s, was officially adopted by Henry VII in 1497. It was the legal system for weighing precious metals, gems, coinage, and bread (Ross 1983, Cardarelli 2003). Its name derives from the town of Troyes (Northern France). The basic unit was the troy pound $(=5,760$ grains $=0.3732417216 \mathrm{~kg})$, the other units being the ounce, the pennyweight, and the grain. The troy grain was equal to the grain avoirdupois.

The troy system was the basis for the apothecary weight system used commonly by medieval medical practitioners due to its good representation of small quantities. Its basic measure unit was the ounce. The other units were the pound, the grain, the drachm, and the scruple. The last one was adopted from the classical Roman system. One apothecary ounce equalled the troy ounce. However, in the troy system an ounce was divided into 20 pennyweight, whereas in the apothecary system into $8 \mathrm{dra}(\mathrm{ch}) \mathrm{ms}$ (see Table 2 above for a comparison of the two systems). The apothecary system of units was similar to that used by the School of Salerno (the world's first medical school, originally the dispensary of a monastery founded in the $9^{\text {th }}$ century), with the only exception concerning the division of an ounce (into 8 drachms in the apothecary system and 9 drachms in the Salerno system).

Most of these terms have their own abbreviated forms, which are found mostly in medical recipes. One such text, a $15^{\text {th }}$ century translation of the Latin Thesaurus Pauperum, includes a short guide which explains the most common Latin terms and measures and their abbreviations. In the last two lines the author of the text focuses also on the fact that there might be other weight systems (here the marchaunts' system) whose values differ considerably and which should not be used in the preparation of medicaments, cf.: 
Brother leches haue a queynt maner writyng and hard for to rede in makyng of hir medicynes. Brother when ye seeth in bookes of phisique thes writynges $\mathbf{R}$ that is comynly the begynnyng of hir medicines ye shul vnderstond Recipe that is to say take. Ana is as moche for to say as of iche ilich moche. A pound is writen thus li. $\mathbf{j}$. and li. ij and half a pound thus li. di. othur thus li. $\boldsymbol{\beta}$. A quarter of a pound is writen thus qrt. li. An handful is writen thus. M. j. Half an handful is wryten thus M. $\boldsymbol{\beta}$ or thus M. di. An vnce is writen thus $\bar{\xi}$ outher thus j vnce. Half an vnce is writen thus $3 \beta$ outher thus $3 \mathrm{di}$. And a quarter of an vnce is writen thus $3 \mathrm{ij}$. Also a dragme is writen thus $\mathbf{3} \mathbf{j}$. And half a dragme is writen thus $\boldsymbol{3} \boldsymbol{\beta}$ outher thus $3 \mathbf{d i}$. A scripulle is written thus $\mathbf{3} \mathbf{j}$. And ye shul vnderstond that thre scripulles maken a dragme and viij dragmes maketh an vnce and xij vncez maketh a pound. And somme men take xvj vnces for a pound as marchauntes don but phisiciens for the more part taketh xij $\xi$ for a li.

(MEMT, Thesaurus Pauperum)

Both systems became obsolete in the UK. The troy system, however, survived in the USA. The values for the particular units in both systems are shown in Table 2 above.

\subsection{The major units of measure}

\subsubsection{The stone}

Stone (f. OE stān) was used as a measure term from the end of the $14^{\text {th }}$ century. Following the $O E D$, it referred to "a measure of weight, usually equal to 14 pounds avoirdupois ( $1 / 8$ of a hundredweight, or half a quarter), but varying with different commodities from 8 to 24 pounds" (s.v. stone n. 14a).

\subsubsection{The clove}

The original reference of clove is Latin clāvus 'nail', which was used as a lineal measure. It is related to AN clou, which denoted 'measure of weight' (AND: s.v. clou 4). In the $14^{\text {th }}$ century it started to be used as a unit of weight applied to wool and cheese. According to the $O E D$ (s.v. clove n. ${ }^{3}$ ), a clove equalled 7 or 8 pounds avoirdupois and was used until the end of the $19^{\text {th }}$ century.

\subsubsection{The pound}

The form derives from classical Latin *pondus 'by weight'. Originally used with the numeral, it was reinterpreted in Germanic as denoting a unit of weight. Following the $O E D$ (s.v. pound n. ${ }^{1}$ ), the early borrowing resulted from trade and the necessity for accurate measures. 
By medieval times the pound became a universal unit of measure. However, it was used in a variety of contexts. Not only was it the unit of weight but also capacity and money.

In 1303 the Assize of Weights and Measures in England decreed that an English penny shall weigh 32 grains of wheat dry and twenty pence make an ounce. 12 ounces make a pound and a gallon of wine weighs 8 pounds. (...) This pound was the Tower pound so that the pound (money) was a pound weight of silver and made 240 silver pennies

(Andrew 2008).

Additionally, by the end of the century two more pounds were introduced, the troy pound and the avoirdupois pound, which were in use until metrication. In the $O E D$, we read:

The pound was originally made up of 12 ounces, as in the system of troy weight
which is still used in stating the weight of precious metals; but as early as the $13^{\text {th }}$
cent. a merchant's pound of 15 ounces was in use for more bulky commodities. In
the $14^{\text {th }}$ cent. this was replaced by a pound of 16 ounces, which was made a
standard for general purposes of trade by Edward III, and known as the pound
aveir de peis, i.e. of merchandise of weight

(OED: s.v. pound n. $\left.{ }^{1}\right)$.

\subsubsection{The ounce}

The form used in Old English was derived from an unattested post-classical Latin variant of uncia 'the twelfth part'. In Middle English it was reborrowed from Anglo-Norman and Middle French unce (ounce, ounse, once). It was used with reference to 'a unit of weight' and 'an inch' (OED, AND). As a unit of measure, the ounce referred to 'a unit of weight equal to (a) one-twelfth of a pound in troy and apothecaries' measure, equal to 480 grains (= 31.1 grams); (b) one-sixteenth of a pound in avoirdupois measure $(=\sim 28.3$ grams)' $(O E D)$. Following the dictionary, from the $14^{\text {th }}$ century it could also denote 'a small quantity or amount' (s.v. ounce, n. ${ }^{1}$ I.1.c).

\subsubsection{The dra(ch)m}

The term derives from OF dragme or L dragma (f. Greek drakhme, i.e., an Attic weight and coin). Originally it denoted 'a handful of coins' (Hoad 1993: s.v. drachm). The lexeme was used in English from the $14^{\text {th }}$ century with the senses: 'the principal silver coin of the ancient Greeks' and 'a weight approximately equivalent to that of the Greek coin. Hence, in the apothecaries' weight $=60$ grains, or $1 / 8$ of an ounce, in the avoirdupois weight $=27 \frac{1}{3}$ grains or $1 / 16$ of an ounce' $(O E D)$. 


\subsubsection{The pennyweight}

The pennyweight, from Old English peningwaeg, is a unit of weight equal to 24 grains (i.e., $1 / 20$ troy ounce, $\sim 1.56$ grams), and formerly to $1 / 240$ tower pound (i.e., $22 \frac{1}{2}$ grains, $\sim 1.46$ grams), which was the actual weight of a silver penny.

\subsubsection{The scruple}

Scruple was derived from Latin scrüpulus, scrüpulum. Following the $O E D$ (s.v. scruple $\left.\mathrm{n} .{ }^{1}\right)$, the sense 'small unit of weight or measurement' developed from the sense 'small pebble' (cf. OED: s.v. scruple n. ${ }^{2}$ ). It was used in English from the $14^{\text {th }}$ century as a unit of weight equal to 20 grains, $1 / 3$ drachm, or $1 / 24$ ounce of the apothecaries' weight.

\subsubsection{The grain}

The origin of grain can be found in (a) OF grain, grein (f. Lat. grānum 'a grain, seed') and (b) OF grain(n)e (f. Lat. grāna, i.e., plural of grānum), being the collective noun for seeds. As a unit of measure, it refers to the smallest English and US unit of weight equal to $1 / 5760$ of the troy pound and $1 / 7000$ of the avoirdupois pound. Following the $O E D$, grain with reference to measure was first used in the $16^{\text {th }}$ century (s.v. grain $n .{ }^{1}$ II.8).

\section{The corpus}

The corpus used for the present study has been divided into the culinary and the medical database. The earliest culinary material comes from the $14^{\text {th }}$ century, and thus, even though in the case of medical recipes much earlier texts are available, it has been decided that the present research shall be based on recipes from the $14^{\text {th }}$ and $15^{\text {th }}$ centuries. Unfortunately, the former century is highly underrepresented when compared to the number of texts written in the $15^{\text {th }}$ century (both culinary and medical). In the latter period, the available medical corpus is much bigger than the culinary one. And thus, it has been decided that for the $14^{\text {th }}$ century, all the texts available will be included in the corpus, whilst for the $15^{\text {th }}$ century a comparable sample of the two types of texts will be selected.

Altogether, the culinary database consists of texts of 117,400 words (i.e., 28,400 words from the $14^{\text {th }}$ and 89,000 from the $15^{\text {th }}$ centuries), whilst the medical database consists of texts with a total of about 105,200 words (i.e., 
14,000 words from the $14^{\text {th }}$ and 91,200 from the $15^{\text {th }}$ centuries).${ }^{14}$ Table 3 shows the exact number of recipes selected to represent each of the centuries and their length. Due to the discrepancies between the length of the culinary and medical recipes, in order to make the comparison between these two reliable, in what follows, next to the absolute frequencies of occurrence of the analysed measure terms, the relative frequencies will be given, normalised to 1,000 words.

Table 3. The size of the corpus [CR = culinary recipe; $\mathrm{MR}=$ medical recipe $]$

\begin{tabular}{l|c|c|c|c}
\hline period: & Nr of MRs & $\begin{array}{c}\text { Nr of words } \\
\text { (MR) }\end{array}$ & Nr of CRs & $\begin{array}{c}\text { Nr of words } \\
\text { (CR) }\end{array}$ \\
\hline $14^{\text {th }}$ c. & 304 & 14,041 & 422 & 28,362 \\
\cline { 2 - 5 } $15^{\text {th }}$ c. & 336 & 91,186 & 1,049 & 89,027 \\
\hline
\end{tabular}

The culinary database consists of recipes found in Hieatt \& Butler's Forme of Cury ( $14^{\text {th }}$ century), Austin's Two $15^{\text {th }}$ century cookery books $\left(15^{\text {th }}\right.$ century), Hieatt's $A$ gathering of Medieval English recipes $\left(14^{\text {th }}\right.$ and $15^{\text {th }}$ century) and a part of Hieatt's An ordinance of pottage ( $15^{\text {th }}$ century).

The medical material selected for the analysis includes recipes derived from two texts, Antidotarium Nicholai and Gilbertus Anglicus, which are two $15^{\text {th }}$ century translations of Latin originals. The former was written by Nicolaus Salernitanus, a $12^{\text {th }}$ century teacher in the Medical School of Salerno. It is the most representative collection of recipes included in the Remedies and materia medica section of MEMT $^{15}$. Each recipe starts with a name of a medicine followed by an explanation on the origins of the name and by instructions of how a given medicine should be prepared and administered. ${ }^{16}$ The latter text

14 The numbers based on the automatic word count in .docx files

15 There have been several attempts to categorise Middle English medical material, e.g., (i) the division of medical texts according to their content (e.g., Robbins (1970) divides the texts into three groups: prognosis, diagnosis, or treatment; Alonso Almeida \& Carroll (2004), on the other hand, classify them as theory-only books, theory-only practice books, and practice-only books); (ii) the division according to the audience or origin (Voigts' (1982) academic/learned treatises and popular remedy books or Taavitsainen's (2001a) Specialised texts, Surgical texts, and Remedies and materia medica). In the present study we have decided to adopt Taavitsainen's (2001a) classification of texts. The medical material was extracted from the texts that belong to the category Remedies and materia medica. The texts included in this category represent the oldest tradition of medical writing and are often regarded as those representing a less learned tradition of writing. Due to the fact that the culinary recipes are non-learned texts, we have decided to exclude from the present study recipes found in the writings representing academic tradition (surgical texts and specialised treatises).

16 For more on Antidotarium Nicholai see, e.g., Carillo-Linares (2005) or Pocuca \& Stupar (2006). 
dates back to about 1250 and was written by Gilbertus Anglicus. In this text, unlike in the Antidotarium Nicholai, recipes are part of longer texts, arranged in a head to foot order, and consisting of descriptions of sicknesses and their symptoms (Getz 1991). The medical material has been supplemented with two collections (First corpus compendium and Second corpus compendium) written in the first half of the $14^{\text {th }}$ century, included in the Appendix to the MEMT corpus. The former contains almost an equal number of recipes in English, Latin, and French, whereas in the latter collection most examples are in English. They represent the earliest phase of vernacular medicine.

4. Measure and weight units used in the corpus

\subsection{Classification of measures/weights}

The measure terms used in the texts analysed for the present study can be grouped into three major categories, i.e., specific, non-specific, and containerrelated terms. ${ }^{17}$ The first category includes terms whose quantity is precise, for instance, it might be recognised by a commonly used measure system, the nonspecific terms include terms such as plenty, little, a quantity, etc., which refer to the amount or number in a non-/less-specific way, whereas the last category refers to terms formed usually with the suffix -ful attached to the noun specifying the type of a 'container', e.g., dishful, egg-shellful, potful, etc. The absence of measure terms has not been counted.

\subsubsection{Specific terms}

This group of terms consists of units of measure whose weight is specified by a particular weight system (here Troy and Apothecaries' systems). The following specific measure terms have been found in the analysed material: cornweight, dragme, grain, ounce, pennyweight, pound, scriple, and sixter. Their distribution in medical and culinary texts is shown in Table 4.

17 Carroll (2009) distinguishes a) precise (specified) quantities and b) vague (approximated) quantities. See also Channell (1994). 
Table 4. The number of occurrences of the specific terms of measure found in the analysed texts. The relative normalized frequencies have been given in brackets [per 1,000 words].

\begin{tabular}{l|c|c|c|c}
\hline \multirow{2}{*}{ Weights: } & \multicolumn{2}{|c|}{ medical recipes } & \multicolumn{2}{c}{ culinary recipes } \\
\cline { 2 - 5 } & $\mathbf{1 4}^{\text {th }} \mathbf{c .}$ & $\mathbf{1 5}^{\text {th }} \mathbf{c .}$ & $\mathbf{1 4}^{\text {th }} \mathbf{c .}$ & $\mathbf{1 5}^{\text {th }} \mathbf{c .}$ \\
\hline corn (weight) & $5[0.4]$ & $125[1.4]$ & - & - \\
\hline dra(ch)m & - & $567[6.2]$ & - & - \\
\hline grain & - & $16[0.2]$ & - & - \\
\hline ounce & $17[1.2]$ & $248[2.7]$ & $35[1.2]$ & $9[0.1]$ \\
\hline pennyweight & $1[0.07]$ & $1[0.01]$ & $3[0.1]$ & $3[0.03]$ \\
\hline pound & $1[0.07]$ & $128[1.4]$ & $16[0.6]$ & $19[0.2]$ \\
\hline scruple & - & $133[1.5]$ & - & - \\
\hline sixter & - & - & - & $1[0.01]$ \\
\hline TOTAL & $\mathbf{2 4}[\mathbf{1 . 7}]$ & $\mathbf{1 , 2 1 8}[\mathbf{1 3 . 4}]$ & $\mathbf{5 4}[\mathbf{1 . 9}]$ & $\mathbf{3 2}[\mathbf{0 . 3}]$ \\
\hline
\end{tabular}

The occurrences of such units as pound, ounce, pennyweight, or corn (= grain) in the $14^{\text {th }}$ century texts (both culinary and medical) are scarce and random. In the case of the medical material, this might be explained by the fact that the earliest medical recipes were often of less learned character (cf. the discussion of receptaria in section 1.2) and included folk medicine which often relied on less determined weights and measures. Moreover, in the $14^{\text {th }}$ century, the weight system for small quantity (as for instance the Apothecaries' system) was still not common (at least in England). Thus, if there occur any specific terms, it seems to result from the mere copying of foreign originals, see examples (3a) and $(3 b)$ below.

(3a)

[\}Pur le chef.\}] [\1〉] Pernes .ii. unces de betoyne e .iii. unces de here to[\{re\{]stre, 'pat is heyhowe,' e .viii. unces de puliole, patys hulwrt', e les fettis brayer en une morter. E kant sette iii. herbes sunt ben braes, fettes lez frire en une payele de oyle de olive e mettez deins le payele un unce de sire verge e i. quarterun de fraunc encens ben molu.

(MEMT, First Corpus Compendium)

[163।] For pe heued pat is broken in pe bone: Tac an hanful of malws and an handful of wyrmoid and an handful of mugwede and stampe hem togedere. And tac .iiii. vnces of quete flour or of barlich-flour and .iiii. vncez of huny and reid wyne an 
.iiij. vncez of galt-smere, and of pat gres so do in a panne and melt it and maket hoyt, and do mack a plaistre, and ley it to be heued al warm.

(MEMT, First Corpus Compendium)

These two extracts come from a $14^{\text {th }}$ century manuscript that has an almost equal number of medical recipes in English, Latin, and French. As the examples above show the compiler of the text when rendering the unit of weight uses the French unit of weight and time, i.e., unce.

In the $15^{\text {th }}$ century medical texts units of weight characteristic for the Apothecaries' system are preferred. This might be explained by the fact that most English medical texts which date back to the $15^{\text {th }}$ century are translations of Latin originals whose traditions of scientific writing were well established and, hence, characterized by a more learned approach towards medical treatment and the preparation of medicaments (including the measure system). For instance, the author of the Latin Antidotarium Nicholai systematized the rules concerning the preparation of medicaments and introduced a new measurement system that allowed physicians to prepare small quantities of pharmaceutical forms (Carrillo-Linares 2005; Pocuca \& Stupar 2006: 49). This was a compulsory text at a number of universities and became the basis for other pharmaceutical texts that were produced in medieval Europe. Thus, anyone involved in the medical practice was expected to be acquainted with the content of the text. This implies that English physicians, having access to the Latin originals, were familiar with Latin measure system used in pharmaceutical practice. Thus, the use of these terms in the English version, without any further explanation, was the logical choice of a translator, often being a physician himself. In addition, the use of these terms overlaps, somehow, with the official establishment of the Troy and Apothecaries' systems in the $15^{\text {th }}$ century England.

The culinary recipes (of both the $14^{\text {th }}$ and $15^{\text {th }}$ centuries) contain hardly any specific units of measure, which shows how imprecise they were. The greatest number of specific terms, pound and ounce, were found in the $14^{\text {th }}$ century; however, it has to be underlined that the majority of these occurrences were found in only a few recipes belonging to the same collection (Goud Kokery) and dated to 1380 and 1395 . It should be noticed that the most precise of the recipes referred usually to drinks, see example (4), and seem to be translations.

(4)

Potus clarreti pro domino. Take of canel $\mathbf{i} \mathbf{~ l b . ~ / ~ a s ~ i t ~ c o m e p ~ o u t ~ o f ~ p e ~ b a l e ; ~ o f ~}$ gyngyuer, xii unce in pe same maner; iii quarter of a lb. of pepir; ii unce of longe peper; ii unce $\boldsymbol{\&}$ a half of greynes; iii unce of carewey; ii unce of macis; 
ii unce of notemugges; ii unce of coliaundir; a quarter of a pynte of aqua ardaunt; with ii galouns of hony: rescett for $\mathbf{x x}$ galouns of clarrey.

(Goud Kokery_ Potus clarreti pro domino)

Similarly in the $15^{\text {th }}$ century, the precise recipes usually referred to drinks; see the recipe under (5), which dates back to 1485 .

(5)

To make clarrye.

Take a galoun off white wyne, $\mathbf{i j}$ lib sugur, vj unce synamon, $\mathbf{i j}$ unces greynes, j unce cardamom, ij unce galingale: meng wyne \& pouder togeder \& lette yt penn thoro a bag lyke as pu doyst ypocras.

(Gathering of Middle English Recipes_CUL_To make clarrye)

A few times the measure unit was clarified, as if to explain it to the cook, e.g., (6), which proves that the use of measure units might not have been widespread. In the $14^{\text {th }}$ century material one recipe even specifies which measure system to follow, by calling for 'Troy ounce'.

(6)

Take a mesoure of wyne pat man clepethe a sexter (...)

(Gathering of Middle English Recipes_eMus_For to make Aqua Arden)

Such a small number of specific measurements in the medieval culinary recipes supports the assumption that they were used by readers familiar with the dishes and cooking. As Carroll (2009: 80) writes: "when a writer assumes familiarity and experience on the part of the reader, it is possible to omit a great deal of this specification, even to the extreme...".

\subsubsection{Non-specific terms}

The second group of measure terms consists of items with a more general sense, which are not characterised by exact values or quantities; hence they will be referred to as 'non-specific terms'. These include:

- deal: a (good/great) deal of

- enough

- (a) few

- great: as gret as as nedep, suffice

- heap

- (a) little

- much: solas much as (nedep, sufficep) 
- $\operatorname{part}(y): a(\operatorname{good} /$ fourth) $\operatorname{part}(y)$ of

- piece

- plenty

- portion: a (good/great) portion of

- quantity: a (good/great) quantity of

- quarter

The frequency of the occurrence of these terms is shown in Table 5 below.

Table 5. The number of occurrences of the non-specific terms found in the analysed corpus. The relative normalized frequencies have been given in brackets [per 1,000 words].

\begin{tabular}{|c|c|c|c|c|}
\hline \multirow{2}{*}{ 'measure' } & \multicolumn{2}{|c|}{ medical recipes } & \multicolumn{2}{|c|}{ culinary recipes } \\
\hline & $14^{\text {th }} \mathrm{c}$. & $15^{\text {th }} \mathrm{c}$. & $14^{\text {th }} \mathrm{c}$. & $15^{\text {th }} \mathrm{c}$ \\
\hline ana / yliche moche & - & 84 [0.9] & - & - \\
\hline deal (a good/great of) & - & - & $10[0.4]$ & $41[0.5]$ \\
\hline enough & - & - & $5[0.2]$ & 112 [1.3] \\
\hline few $(\mathrm{a} \sim)$ & - & - & $2[0.07]$ & $11[0.1]$ \\
\hline heap & - & - & & $3[0.03]$ \\
\hline little $(\mathrm{a} \sim$ of $)$ & $10[0.7]$ & $11[0.1]$ & 53 [1.9] & $268[3]$ \\
\hline much (so/as as) & $44[3.1]$ & $63[0.7]$ & $3[0.1]$ & $28[0.3]$ \\
\hline $\operatorname{part}(\mathrm{a} \sim \mathrm{of})$ & $10[0.7]$ & $13[0.1]$ & $32[1.1]$ & $31[0.3]$ \\
\hline pennyworth & - & - & $4[0.1]$ & $1[0.01]$ \\
\hline piece & - & - & - & $10[0.1]$ \\
\hline plenty & - & - & $11[0.4]$ & $2[0.02$ \\
\hline $\begin{array}{l}\text { portion } \\
\text { (a good/great } \sim \text { of })\end{array}$ & - & - & $10[0.4]$ & $37[0.4]$ \\
\hline $\begin{array}{l}\text { quantity } \\
\text { (a good/ great/little } \sim \text { of) }\end{array}$ & - & $52[0.6]$ & $16[0.6]$ & $105[1.2]$ \\
\hline quarter & - & $3[0.03]$ & $9[0.3]$ & $16[0.2]$ \\
\hline some & - & - & - & $2[0.02]$ \\
\hline TOTAL & $64[4.6]$ & 226 [2.5] & $155[5.6]$ & $667[7.5]$ \\
\hline
\end{tabular}

The results presented in Table 5 reveal that with time the writers/compilers of medical recipes tend to avoid non-specific measures (cf. RNF 4.6 in the $14^{\text {th }}$ century vs. 2.5 in the $15^{\text {th }}$ century). These terms, if found in a recipe, were mostly 
used with ingredients that were not meant to cure but to improve the taste or consistency/density of a medicament. For instance, the measures as much as, a little or quantity of are usually used with sweetening ingredients (honey, sugar, syrup of roses/violets, water of roses) or oily substances (oil or butter), cf.:

(7)

Take aloes epatic or cicotrine, V dragmes and half and VI corne wyght; (...); hony or sucre as moche as [lf. 6rl] suffyzep. Be yt zeue an eue on the maner of a chasteyne.

(MEMT, Antidotarium Nicholai)

Take lapdanum ypurede, IIII ounces; fyn storax calamyte, an ounce and half; (...); water of roses as moche as suffyzep.

(MEMT, Antidotarium Nicholai)

(9)

(...) and afterwarde, take a quantite of water of roses ymedled wyp muske (...)

(MEMT, Antidotarium Nicholai)

Take rwe, and onyons, and a litil oyle, and medle hem togedre.

(Getz, Gilbertus Anglicus)

Đen strene it and put perto oyle of violet or oyle de olijf and and a litil bottir.

(Getz, Gilbertus Anglicus)

In addition, the expression a quantity of is often found in the context specifying the form/size of the medicament to be given to a patient, see (12)-(14).

Be yt zef on pe quantite of a gret walnote, after a bathe wyp hoote water.

(MEMT, Antidotarium Nicholai)

(...) and panne make perof smalle ballys on pe quantite of a cherye, (...).

(MEMT, Antidotarium Nicholai)

And make of hem pillulis of pe quantite of a pees (...)

(Getz, Gilbertus Anglicus) 
Sometimes, the choice of the amount of the ingredients relied on the person involved in the healing practice, which suggests that medical texts were usually directed to experienced medical practitioners rather than laymen. For instance, in many recipes the ingredients are not followed by a precise weight but by an expression yliche moche, which allows the physician to decide on the amount of the ingredients, e.g. (15)-(16).

Take of storax, mire, opium, ana, id est, yliche moche.

(Getz, Gilbertus Anglicus)

(...) 3yue him to drinke of pe syrip of fumiter and oximel y-medlid togedir, of bope iliche moche.

(Getz, Gilbertus Anglicus)

Interestingly, the term ana, a Latin equivalent of yliche moche (see (15) above), is often followed by a specified weight. The fact that Lat. ana is not found in all instructions implies that the writer/author of a given recipe might have wanted to emphasize the importance of the use of exactly the same amount of listed ingredients, see (17).

Take of fenel seed, a pounde; of ameos, anet, carewei, ana, half a pounde; of ysope, piliol, origane, calamite, ana, oz. i; of cardamomum, of canel, ana, oz. $1 / 2$; of folie, of ginger, ana, dr. ii.

(Getz, Gilbertus Anglicus)

The culinary recipes are definitely much richer in the non-specific terms than in the specific ones. The use of the 'vague measurements', as Carroll (2009) calls them, shows that a lot depended on the cook. He was to decide what exactly enough or $a$ portion of meant. Even when the exact number of something (such as eggs) could have been given, the recipe was imprecise, as in (18), and the cook was given the choice, see examples (18)-(22). The reason for such a lack of precision has been suggested for instance by Carroll (2009) and Diemer (2013: 140), who writes: "Middle English recipes, for example, are clearly made for professional cooks, since the modern measurements are almost completely missing".

(...) \& take zolkys of Eyroun nowt to fewe, ne nozt to many,

(Bake Metis_Daryoles) 
(19)

Drawe it vp with gode rede wyne, and do perin sugur ynowh3 with powdour fort $(\ldots)$

(Forme of Cury_Sawse Sarzyne)

(20)

(...) an yf pe mylke be nozt swete y-now, take whyte sugre an caste per-to.

(Potage Diverse_Froyde almounys)

(21)

And if pou seest that hit hath to litull of the vinegre, or salt, or saffron, caste thereto more, after thi discrecion;

(Boke of Kokery_Gely)

(...) \& caste in a quantite as pu semest beste;

(Gathering of Middle English Recipes_eMus_Bake mete praty upon)

We may assume that the recipes only suggested whether there should be a lot or little of a particular ingredient, since differences such as a quantity of vs. $a$ great quantity of, or a portion and a good portion, etc., are frequent, see for instance (23)-(25). Additionally, we may agree with Bubel \& Spitz (2013) that such measure terms require that the cook is a professional familiar with cooking practices. ${ }^{18}$

Tak percely, a good quantitie, \& a litel peletre, (...)

(Forme of Cury_Vertesaus broun)

(...) take mylke of almaundys, an cast per-to, \& hony, nowt to moche, pat it be nowt to swete,

(Potage Diverse_Whyte wortes)

(...) \& put Sugre a gode quantyte per-to, or hony, but nowt to moche;

(Potage Diverse_A potage on fysshday)

18 Bubel \& Spitz (2013: 162) give the examples of measure terms such as 'to taste' and 'a pinch of'. 
Sometimes to emphasize the abundance of something, a number of synonymous terms were used next to each other, e.g.,

(...) poudre of couwes of gilofre, muche plente of ayren monie, \& sucre gret plente vorte abaten pe streynpe of pe spicerire;

(Diversa Cibaria_Bruet salmene)

In a number of cases, the cook was given hints what effect to achieve by adding a particular ingredient rather than the exact measures, e.g.,

(...) tak salt, \& do (...) bat be so salt als water of pe see and moche more.

(Diversa Servisa_For to kepe venisoun fro restyng)

(...) poudre of gyngere so pat hit smacche wel of pe gynger,

(Diversa Cibaria_Viaunde de Cypre)

(...) \& meng pam togedere wyp fayr grees so pat yt be fat ynow,

(Diversa Servisa_For to make Bruet of Lombardye)

Even when the exact numbers were given, the cook still had the choice, e.g., (30). Very often the cook was supposed to adjust the amount of a particular ingredient to the occasion, number of people, tastes of the host, etc., as in (31)(32).

(30)

For to make a porrey chapeleyn, tak an hundred onyons oper an half, \& tak (...)

(Diversa Servisa_For to make a Porrey Chapeleyn)

(...) \& couche aboue poudere of gyngere as pe quantite of py seruise nedeth.

(Utilis Coquinario_For to make eles in counfy)

Careawey, cirmunteyn, comyn, fenel, smallage, persile, sauge, myntis, ruwe, calamynte, origanum: and a half unce or moore or lasse, as pee likip.

(Goud Kokery_Aqua vite) 
A common tendency was to present proportions of the particular ingredients, as in (33)-(37). This proves that a particular recipe was not designed for a certain number of people, but could have been modified depending on how much of the dish was needed.

(33)

Do perto half wyne and half water,

(Forme of Cury_Gees in hoggepot)

Take the tweydel of wyne oper the priddell of vyneger;

(Forme of Cury_Egurdouce of fysshe)

Take pe to del zolkys of eyron, pe pridde dele Hony;

(Potage Diverse_Vyaund de ciprys Ryalle)

Lye it vp almost wip as myche various as water;

(Forme of Cury_Crustardes of eerbis on fyssh day)

Take Wyne, Canel, an powder of Gyngere, an Suge, an of eche a porcyoun, (...)

(Potage Diverse_Soupes Jamberlayne)

\subsubsection{Container-related terms}

This category comprises units whose quantity is specified by the type of a 'container' (spoon, hand, pot, etc.). Due to the fact that no clear statement on the size of the container is ever given, this group goes somewhere between the specific and non-specific measure terms discussed in the previous sections. The terms found in the analysed material which belong to this group are cupful, eggshellful, handful, panful, potful, spoonful, and phrases formed from the name of a container and the preposition of, such as a pot of, a dish of. The number of occurrences of the particular terms is given in Table 6 . 
Table 6. The number of occurrences of the container-related terms found in the analysed corpus. The relative normalized frequencies have been given in brackets [per 1,000 words].

\begin{tabular}{l|c|c|c|c}
\hline \multirow{2}{*}{ 'measure' } & \multicolumn{2}{|c|}{ medical recipes } & \multicolumn{2}{c}{ culinary recipes } \\
\cline { 2 - 5 } & $\mathbf{1 4}^{\text {th }} \mathbf{c}$. & $\mathbf{1 5}^{\text {th }} \mathbf{c}$. & $\mathbf{1 4}^{\text {th }} \mathbf{c .}$ & $\mathbf{1 5}^{\text {th }} \mathbf{c}$ \\
\hline chaferful & - & - & - & $2[0.02]$ \\
\hline cupful & $5[0.4]$ & - & $1[0.03]$ & $3[0.03]$ \\
\hline dishful & & - & $1[0.03]$ & $5[0.06]$ \\
\hline egg-shellful & $6[0.4]$ & - & - & - \\
\hline halfful & - & - & - & $2[0.02]$ \\
\hline handful & $10[0.7]$ & $4[0.04]$ & - & $5[0.06]$ \\
\hline ladelful & - & - & - & $2[0.02]$ \\
\hline panful & $1[0.07]$ & - & - & $1[0.01$ \\
\hline potful & $1[0.07]$ & - & - & $1[0.01$ \\
\hline saucerful & - & - & - & $1[0.01$ \\
\hline spoonful & $11[0.8]$ & $18[0.2]$ & - & $5[0.06$ \\
\hline a 'container' of & - & - & - & $5[0.06$ \\
\hline TOTAL & $\mathbf{3 4}[\mathbf{2 . 4}]$ & $\mathbf{2 2}[\mathbf{0 . 3}]$ & $\mathbf{2}[\mathbf{0 . 0 7}]$ & $\mathbf{3 2}[\mathbf{0 . 4}]$ \\
\hline
\end{tabular}

It is surprising that the typically culinary way of giving measures, i.e., by combining the name of a container with the suffix -ful, e.g., cupful, dishful, etc. was so rare in the analysed culinary texts, with fewer than one occurrence per 1,000 words. Nevertheless, the examples which were found reveal a great variety of such measure terms, see Table 6 and the examples below.

pan caste a ladelful, or more or lasse, of boter perto,

(Potage Diverse_Vyaund leche)

And then take a chaffurful of fressh grece boyling;

(Boke of Kokery_Cryspes)

As stated earlier (see section 2) early medieval medical practitioners and compilers did not have a single, commonly agreed weight system that could have been used in the preparation of medicine. Hence, they often turned to units 
of weight typical of culinary recipes (cupful, handful, spoonful, etc.). ${ }^{19}$ Although less precise ${ }^{20}$, these weights at least allowed physicians to ensure that the proper proportions of ingredients were maintained.

\section{Conclusions}

The present paper, being another contribution to the study of medieval recipes, offers a comparative analysis of the use of measurements in medical and culinary instructions. Altogether 2,111 recipes from the $14^{\text {th }}$ and $15^{\text {th }}$ centuries were analysed (640 medical and 1,471 culinary). They were selected in such a way as to represent samples of similar length for the two recipe types. The measure terms extracted from the material were categorised into three groups: the specific, non-specific, and container-related terms. The total number of items collected equalled 1,588 within the medical corpus and 934 within the culinary corpus (see Table 7 for details).

Table 7. The total number of occurrences of terms of measure and weight belonging to particular categories. The relative normalized frequencies have been given in brackets [per 1,000 words].

\begin{tabular}{l|c|c|c|c}
\hline \multirow{2}{*}{} & \multicolumn{2}{|c|}{ medical recipes } & \multicolumn{2}{c}{ culinary recipes } \\
\cline { 2 - 5 } & $\mathbf{1 4}^{\text {th }} \mathbf{c}$. & $\mathbf{1 5}^{\text {th }} \mathbf{c}$. & $\mathbf{1 4}^{\text {th }} \mathbf{c}$. & $\mathbf{1 5}^{\text {th }} \mathbf{c}$. \\
\hline \multirow{2}{*}{$\begin{array}{l}\text { npecific: } \\
\text { non-specific } \\
\text { container- } \\
\text { related terms }\end{array}$} & $24[1.7]$ & $1,218[13.4]$ & $54[1.9]$ & $32[0.3]$ \\
\cline { 2 - 5 } & $64[4.6]$ & $226[2.5]$ & $155[5.6]$ & $667[7.4]$ \\
\hline
\end{tabular}

The study enables one to conclude that Middle English did not lack the proper terminology referring to measure and weight, and the $14^{\text {th }}$ and $15^{\text {th }}$ centuries laid solid foundations for the development of the lexicon referring to measure. Also, the study shows that the use of foreign forms was often not necessary to fill the gaps in the English lexicon of measure words as there were terms in the vernacular that accompanied the foreign element. For instance, in the $14^{\text {th }}$ century medical material the number of specific terms of foreign and native origin are almost equal.

19 Bubel \& Spitz (2013: 162) write about "terms specifying quantities and measures [which] form semantic relations that are often unique to [culinary] recipes".

20 Even though the size of the container has not been specified, Kopaczyk (2013: 269) refers to these terms as 'specific measurements'. Carroll (2009) does not mention them at all. 
As expected, in the medieval medical recipes it is the specific measure terms that prevail, in the culinary texts quite the opposite (see table 7 and figure 2). This could be accounted for by the fact that while the lack of precision in the medical context might have had much more serious effects by even causing the instantaneous death of a patient, in the case of culinary recipes, the imprecision usually would not have had such far reaching consequences. The predominance of the specific terms in the $15^{\text {th }}$ century medical texts can also be explained by a) the easy access to Romance originals; b) the establishment of the measure systems not only in England but also in Europe; and c) a better knowledge of the measure systems.

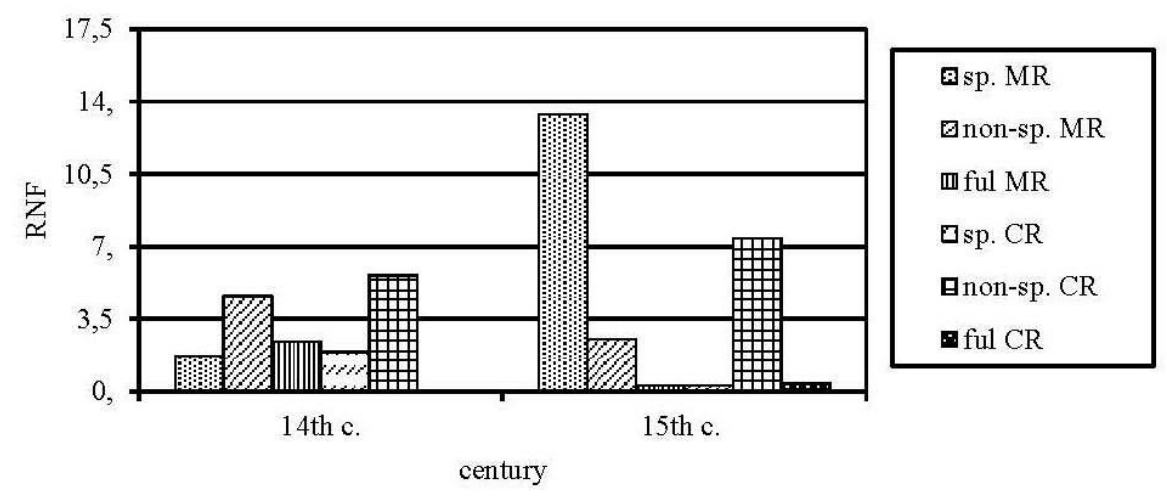

Fig. 2. The ratio of relative normalized frequencies of each of the analysed categories. $[\mathrm{n}$-sp. $=$ non-specific; sp. $=$ specific; ful $=$ container-related terms; $\mathrm{MR}=$ medical recipes $; \mathrm{CR}=$ culinary recipes; $\mathrm{RNF}=$ relative normalized frequency].

What is surprising, the container-related terms did not play an important role in the culinary texts, although the element which specifies the quantity (i.e., the name of a container) implies a typically culinary context. Although the variety of container-related terms is much bigger in the culinary recipes than in the medical material, it is the latter which reveals a greater frequency of usage of these measure terms, especially in the $14^{\text {th }}$ century when specific measure terms were still not as popular as they were a century later. 


\title{
REFERENCES
}

\author{
PRIMARY SOURCES
}

Alonso Almeida, Francisco (ed.). 2014. A Middle English medical remedy book from Glasgow University Library MS Hunter 185. (Middle English Texts 50.) Heidelberg: Universitätsverlag Winter.

[AND] Anglo-Norman Dictionary. http://www.anglo-norman.net/ (June 2014)

Austin, Thomas (ed.). 2000 [1888]. Two fifteenth-century cookery-books: Harleian MS. 279 (ab. 1430), \& Harl. MS. 4016 (ab. 1450), with extracts from Ashmole MS. 1429, Laud MS. 553, \& Douce MS. 55. (Early English Text Society 91.) Woodbridge: Boydell \& Brewer.

Hieatt, Constance B. (ed.). 1988. An ordinance of pottage: An edition of the fifteenth century culinary recipes in Yale University's MS Beinecke 163. London: Prospect Books.

Hieatt, Constance B. (ed.). 2008. A gathering of medieval English recipes. (Textes vernaculaires du Moyen Age 5.) Turnhout: Brepols.

Hieatt, Constance B. \& Sharon Butler (eds.). 1985. Curye on Inglysch: English culinary manuscripts of the fourteenth century (including the Forme of Cury). (Early English Text Society SS 8.) London: Oxford University Press.

[MEMT] Taavitsainen, Irma, Päivi Pahta \& Martti Mäkinen (eds.). 2005. Middle English medical texts. CD-ROM with MEMT Presenter software by Raymond Hickey. Amsterdam/Philadelphia: John Benjamins.

[ODEE] Hoad, Terry F. (ed.). 1993. The concise Oxford dictionary of English etymology. Oxford: Oxford University Press.

[OED] Oxford English dictionary. https://www.oed.com/ (June 2014).

Scully, Terence (ed.). 1997. The Vivendier: A fifteenth century French cookery manuscript. A critical edition with English translation. Totnes: Prospect Books.

\section{SECONDARY SOURCES}

Alonso Almeida, Francisco. 1998-1999. Gyf hyr pis medycyn. Analysing the Middle-English medical recipe discourse. Revista de Lenguas para Fines Especificos 5-6. 49-81.

Alonso Almeida, Francisco. 2008. The Middle English medical charm: Register, genre and text type variables. Neuphilologische Mitteilungen 109(1). 9-38.

Alonso Almeida, Francisco. 2009. Null object in Middle English medical texts. In Javier E. Díaz Vera \& Rosario Caballero (eds.), Textual healing: Studies in Middle English medical, scientific and technical texts, 1-27. Frankfurt am Main: Peter Lang Verlag.

Alonso Almeida, Francisco. 2013. Genre conventions in English recipes, 1600-1800. In Michelle DiMeo \& Sara Pennel (eds.), Reading and writing recipe books, 1550-1800, 68-90. Manchester/New York: Manchester University Press.

Alonso Almeida, Francisco \& Ruth Carroll. 2004. A new proposal for the classification of Middle English medical texts. In Alicia Rodríguez-Álvarez \& Francisco Alonso Almeida (eds.), Voices on the past: Studies in Old and Middle English language and literature, 21-33. A Coruña: Netbiblo. 
Andrew, Jim. 2008 [1970]. Old weights and measures. https://www.museumsassociation.org/download?id=77607 (April 2014).

Bator, Magdalena. 2013a. Verbs of cooking in Middle English: Fry, roast and bake. In Jacek Fisiak \& Magdalena Bator (eds.), Historical English word-formation and semantics (Warsaw Studies in English Language and Literature 15.), 125-138. Frankfurt am Main: Peter Lang Verlag.

Bator, Magdalena. 2013b. Boil vs. seethe in Middle English. In Liliana Sikorska \& Marcin Krygier (eds.), Evur happie \& glorious, ffor I hafe at will grete riches (Medieval English Mirror 9.), 27-40. Frankfurt am Main: Peter Lang Verlag.

Bator, Magdalena. 2014. Culinary verbs in Middle English. Frankfurt am Main: Peter Lang Verlag.

Bator, Magdalena. 2016. On the development of the English culinary recipe. Academic Journal of Modern Philology 5. 7-15.

Bator, Magdalena \& Marta Sylwanowicz. 2017. The typology of medieval recipes - culinary vs. medical. In Jacek Fisiak, Magdalena Bator \& Marta Sylwanowicz (eds.), Essays and studies in Middle English. 9th International Conference on Middle English, Philological School of Higher Education in Wroctaw, 2015, 11-33. Frankfurt am Main: Peter Lang Verlag.

Brears, Peter C. D. 2008. Cooking and dining in Medieval England. Totnes: Prospect Books.

Bubel, Claudia \& Alice Spitz. 2013. The way to intercultural learning is through the stomach Genre-based writing in the EFL classroom. In Cornelia Gerhardt, Maximiliane Frobenius \& Susanne Ley (eds.), Culinary linguistics: The chef's special. (Culture and Language Use 10.), 157-188. Amsterdam: John Benjamins Publishing Company. DOI: $10.1075 / \mathrm{clu} .10 .07 \mathrm{bub}$

Cardarelli, François. 2003. Encyclopaedia of scientific units, weights and measures: Their SI equivalences and origins. London: Springer.

Carroll, Ruth. 1997. Cooking verbs in fourteenth-century English: A semantic class and its syntactic behaviour. Unpublished Ph.D. dissertation: University of Oxford.

Carroll, Ruth. 1999. The Middle English recipe as a text-type. Neuphilologische Mitteilungen 100. 27-42.

Carroll, Ruth. 2004. Middle English recipes: Vernacularization of a text-type. In Irma Taavitsainen \& Päivi Pahta (eds.), Medical and scientific writing in Late Medieval English, 174-197. Cambridge: Cambridge University Press.

Carroll, Ruth. 2005-2006. Assessing palaeographic evidence for discourse structuring in Middle English recipes. Boletín Millares Carlo 24-25. 305-325.

Carroll, Ruth. 2009. Vague language in the medieval recipes of the Forme of Cury. In Matti Peikola, Janne Skaffari \& Sanna-Kaisa Tanskanen (eds.), Instructional writing in English: Studies in honour of Risto Hiltunen, 55-82. Amsterdam: John Benjamins Publishing Company. DOI: 10.1075/pbns.189.07car

Carrillo-Linares, María José. 2005. Middle English Antidotarium Nicholai: Evidence for linguistic distribution and dissemination in the vernacular. International Journal of English Studies 5(2). 71-92.

Channell, Joanna. 1994. Vague language. Oxford: Oxford University Press.

Diemer, Stefan. 2013. Recipes and food discourse in English - a historical menu. In Cornelia Gerhardt, Maximiliane Frobenius \& Susanne Ley (eds.), Culinary linguistics: The chef's special (Culture and Language Use 10.), 139-156. Amsterdam: John Benjamins Publishing Company. DOI: 10.1075/clu.10.06die 
Getz, Faye M. 1991. Healing and society in Medieval England: A Middle English translation of the pharmaceutical writings of Gilbertus Anglicus. Madison: University of Wisconsin Press.

Getz, Faye M. 1998. Medicine in the English Middle Ages. Princeton: Princeton University Press.

Görlach, Manfred. 1992. Text-types and language history: The cookery recipe. In Matti Rissanen et al. (eds.), History of Englishes: New methods and interpretations in historical linguistics, 736-761. Berlin: Mouton de Gruyter. DOI: 10.1515/9783110877007.736

Görlach, Manfred. 2004. Text types and the history of English. (Trends in Linguistics. Studies and Monographs 139.) Berlin: Mouton de Gruyter.

Hammond, Peter W. 2005 [1993]. Food and feast in Medieval England. Stroud: Sutton Publishing.

Henisch, Bridget A. 2009. The medieval cook. Woodbridge: The Boydell Press.

Hunt, Tony. 1990. Popular medicine in thirteenth-century England. Introduction and texts. Cambridge: D.S. Brewer.

Jones, Claire. 1998. Formula and formulation: 'Efficacy phrases' in medieval English medical manuscripts. Neuphilologische Mitteilungen 99(2). 199-209.

Jones, Claire. 2004. Discourse communities and medical texts. In Irma Taavitsainen \& Päivi Pahta (eds.), Medical and scientific writing in Late Medieval English, 23-36. Cambridge: Cambridge University Press.

Jones, Peter. 1999. Medicine and science. In Lotte Hellinga \& Joseph B. Trapp (eds.), The Cambridge history of the book in Britain. Vol. 3, 1400-1557, 433-448. Cambridge: Cambridge University Press. DOI: 10.1017/CHOL9780521573467.023

Kopaczyk, Joanna. 2013. Formulaic discourse across Early Modern English medical genres. Investigating shared lexical bundles. In Andreas H. Jucker et al. (eds.), Meaning in the history of English. Words and texts in context, 257-300. Amsterdam: John Benjamins Publishing Company. DOI: 10.1075/slcs.148.12kop

Laurioux, Bruno. 1999. Medieval cooking. In Jean-Louis Flandrin \& Massimo Montanari (eds.), Food: A culinary history [Translated by Albert Sonnenfeld], 295-301. New York: Columbia University Press.

Mäkinen, Martti. 2004. Herbal recipes and recipes in herbals - intertextuality in early English medical writing. In Irma Taavitsainen \& Päivi Pahta (eds.), Medical and scientific writing in Late Medieval English, 144-173. Cambridge: Cambridge University Press.

Mäkinen, Martti. 2006. Between herbals et alia: Intertextuality in Medieval English herbals. Unpublished Ph.D. dissertation: University of Helsinki.

Marttila, Ville. 2014. Creating digital editions for corpus linguistics: The case of Potage Dyvers, a family of six Middle English recipe collections. Unpublished Ph.D. dissertation: University of Helsinki.

Mennell, Stephen. 1996. All manners of food: Eating and taste in England and France from the Middle Ages to the present. ( $2^{\text {nd }}$ edition.) Urbana, Chicago: University of Illinois Press.

Myers, Daniel. 2006. Making sense of strawberries. An analysis of six related recipes. http://medievalcookery.com/notes/strawberye.pdf (February 2011).

Pahta, Päivi. 2004. Code-switching in medieval medical writing. In Irma Taavitsainen \& Päivi Pahta (eds.), Medical and scientific writing in Late Medieval English, 73-99. Cambridge: Cambridge University Press.

Pahta, Päivi \& Irma Taavitsainen. 2004. Vernacularisation of scientific and medical writing in its sociohistorical context. In Irma Taavitsainen \& Päivi Pahta (eds.), Medical and scientific writing in Late Medieval English, 1-22. Cambridge: Cambridge University Press. 
Pocuca, Marta \& Dragan Stupar. 2006. Pharmaceutical forms in Antidotarium Nicolai. Macedonian Pharmaceutical Bulletin 52(1-2). 49-56.

Robbins, Rossell H. 1970. Medical manuscripts in Middle English. Speculum 45(3). 393-415. DOI: $10.2307 / 2853500$

Ross, Lester A. 1983. Archaeological metrology: English, French, American and Canadian systems of weights and measures for North American historical archaeology. (History and Archaeology 68.) Ottawa: National Historic Parks and Sites Branch, Parks Canada, Environment Canada.

Scully, Terence. 1995. The art of cookery in the Middle Ages. Woodbridge: Boydell Press.

Swales, John. 1990. Genre analysis. English in academic and research settings. Cambridge: Cambridge University Press.

Taavitsainen, Irma. 2001a. Middle English recipes: Genre characteristics, text type features and underlying traditions of writing. Journal of Historical Pragmatics 2(1). 85-113. DOI: 10.1075/jhp.2.1.05taa

Taavitsainen, Irma. 2001b. Changing conventions of writing: The dynamics of genres, text types, and text traditions. European Journal of English Studies 5(2). 139-150.

Taavitsainen, Irma. 2004. Genres of secular instruction: A linguistic history of useful entertainment. Miscelánea: A Journal of English and American Studies. Language and Linguistics 29. 75-94.

Taavitsainen, Irma. 2012. Discourse forms and vernacularisation processes in genres of medical writing 1375-1550. In Anneli Aejmelaeus \& Päivi Pahta (eds.), Translation interpretation - meaning (Collegium. Studies across disciplines in the humanities and social sciences 7.), 91-112. Helsinki: Helsinki Collegium for Advanced Studies.

Tanskanen, Sanna-Kaisa, Janne Skaffari \& Matti Peikola. 2009. Approaching instructional writing in English. In Matti Peikola, Janne Skaffari \& Sanna-Kaisa Tanskanen (eds.), Instructional writing in English: Studies in honour of Risto Hiltunen, 1-11. Amsterdam: John Benjamins Publishing Company. DOI: 10.1075/pbns.189.04tan

Werlich, Egon. 1976. A text grammar of English. Heidelberg: Quelle \& Meyer.

Voigts, Linda E. 1982. Editing Middle English medical texts: Needs and issues. In Trevor H. Levere (ed.), Editing texts in the history of science and medicine: Papers given at the seventeenth annual Conference on Editorial Problems, University of Toronto, 6-7 November 1981, 39-68. New York: Garland.

Zupko, Ronald E. 1990. Revolution in measurement: Western European weights and measures since the age of science. Philadelphia: The American Philosophical Society. 